\title{
THE AUTOMATIC SYNTHESIS OF PETRI NETS BASED ON THE FUNCTIONING OF ARTIFICIAL NEURAL NETWORK
}

Gurskiy A. A. - PhD, Associate Professor of the Department of Technological Processes Automation and Robot-technical Systems, Odessa National Academy of Food Technologies, Odessa, Ukraine.

Denisenko A. V. - Lecturer of the Department of Information Systems, Odessa National Polytechnic University, Odessa, Ukraine.

Dubna S. M. - Lecturer of the Department of Technological Processes Automation and Robot-technical Systems, Odessa National Academy of Food Technologies, Odessa, Ukraine.

\section{ABSTRACT}

Context. The important task was solved during the scientific research related to the development of the methods for automatic synthesis of Petri nets while tuning up of the coordinating automatic control systems. The importance of development of these methods is due to the evolution of intelligent systems. These systems provide the automation of labor intensive processes in the particular case this is the tuning of the certain type of complex control systems.

Objective. The purpose of the scientific work is to minimize the time and automation of process in tuning of the multilevel coordinating automatic control systems.

Method. The principle of automatic synthesis of Petri nets and the implementation of certain algorithms for tuning complex control systems based on the functioning of an artificial neural network are proposed. The mathematical description of the method for changing the coefficients in neural connections of network in the synthesis of Petri nets is presented.

Results. The experiments were conducted in the Matlab $\backslash$ Simulink 2012a environment. These experiments were bound to the joint functioning of an artificial neural network and Petri nets. The functioning of Petri nets was presented in the Matlab $\backslash$ Simulink environment using Statflow diagrams.

As a result of the experiments we have obtained the temporal characteristics of the functioning of artificial neural network providing the composition of Petri nets. The fundamental suitability of using artificial neural network to provide the automatic composition of Petri nets was determined on the basis of analysis of temporal characteristics.

Conclusion. The problem linked to the development of system for the joint functioning of neural network and Petri nets for the formation of algorithms and sequential calculations was solved in this work. Thus the method of automatic synthesis of Petri nets and the method of developing of the certain algorithms based on the functioning of a neural network were further developed.

KEYWORDS: Petri net, artificial neural networks, coordinating automatic control system, algorithms of tuning, automatic synthesis.

\section{ABBREVIATIONS}

PID is a proportional-integral-derivative control;

ANN is an artificial neural network;

ACS is an automatic control system.

\section{NOMENCLATURE}

$M_{k}$ is an $\mathrm{m} \times 1$ vector, the marking after the $k$-th firing;

$|A|$ is an $\mathrm{n} \times \mathrm{m}$ matrix, the incidence matrix of Petri net;

$U_{k}$ is an $\mathrm{n} \times 1$ vector, the control vector indicating the transition fired at the $k$-th firing;

$\mu\left(p_{i}\right)$ is a value of place $p_{i}$ marking;

$w_{i, j}\left(t_{k}\right)$ is the synaptic weight, which determines the corresponding connection in the formed Petri net at step $t_{k}$;

$\varphi(t)$ is a deviation from ratio of the parameters at time $t$;

$X_{1}$ is an actual value of the controlled variable;

$X_{3 Z}$ is a set point of the controlled variable;

$e(t)$ is a deviation of the controlled variable within time from set point;

$A^{T}$ is a coefficient matrix;

$J$ is an integral criterion of system; $u_{1}$, is a control action;

$u_{a}$ is a control action to change the ratio;

$|W|$ is an incidence matrix of the discrete-event part of the system;

$v_{L}^{d}\left(t_{k}\right)$ is a control vector which is formed depending on the fulfillment of conditions for triggering of Petri net transitions;

$$
u_{L}^{d}\left(t_{k}\right) \text { is an input action. }
$$

\section{INTRODUCTION}

The algorithms or sequences of certain implementing computer instructions are usually presented in the form of block diagrams. Such graphical describing of the algorithm is most widespread.

Petri nets are also known as forms of the graphical representation of parallel algorithms and computations. Nevertheless in general, Petri nets are mathematical models of the discrete dynamical systems.

Automatic synthesis of Petri nets is the field of algorithms formation. These algorithms can represent the functioning of discrete or hybrid systems $[1,2]$.

In a particular case the automatic synthesis of Petri nets is expedient in the formation of algorithms for the step-by-step tuning of the certain kind of multi-level automatic control systems. In this case the formation of al- 
gorithms and Petri nets is a necessary component for the automation of the process of tuning in multi-level coordinating control systems [3].

Automation of the tuning process for multi-level automatic control systems is an urgent task as the tuning process is quite difficult. The complexity of the tuning is due to the fact that as a result it is necessary to obtain the temporal subordination of the control processes in the system. If there is no temporal subordination of control processes then the automatic control system will cease to be coordinating.

The object of study is the processes of automatic synthesis of Petri nets while tuning up of the coordinating automatic control systems.

The subject of study is the methods of automatic synthesis of Petri nets while tuning up of the coordinating automatic control systems.

The purpose of the scientific work is to minimize the time and automate of process in tuning of the multilevel coordinating automatic control systems.

\section{PROBLEM STATEMENT}

In order to achieve this purpose we need to develop methods for automatic synthesis of Petri nets which will represent the processes of tuning in the control systems. Considering that the formation of an algorithm is an intelligent process, then it is expedient to synthesize Petri nets based on the functioning of an artificial neural network. In this case the artificial neural network represents an intelligent technology for forming the specific algorithm. Obviously, the training of the neural network should carry out on the basis of the incident matrix of the generated Petri net and on the basis of the values of the performance indicators of the tuning system.

The positive result of automatic synthesis of the Petri net and the corresponding algorithm is the minimization of the values of integral indicators $J_{1}, J_{2}, J_{3}$ of functioning at various stages of the tuning.

In this case, $J_{1}=\int_{0}^{\infty}|\varphi(t)| d t$ is an integral indicator of functioning for the coordinating level of the control system; $J_{2}=\int_{0}^{\infty}(|e(t)|+\alpha \cdot|\varphi(t)|) d t$ is an integral indicator of functioning for the stabilizing level in the control system; $J_{3}=\int_{0}^{\infty}(|e(t)|+\beta \cdot|\varphi(t)|) d t$ is an integral indicator representing the quality of the functioning of the system for tuning to the temporal subordination of the control processes; $\alpha, \beta$ is coefficients determining the temporal subordination of the control processes $(\alpha<\beta) ; \varphi(t)$ is deviation from the ratio of the values of regulated variables; $e(t)$ is the deviation of some variable during time from the given value.

As a result we have to determine all values of the tuning parameters $K \in k_{i j}$ of various levels in the control system according to the formed algorithm. In this case we obtain the minimum values of the $J_{1}, J_{2}, J_{3}$ integral indicators of the multilevel system.

\section{REVIEW OF THE LITERATURE}

The relevance of developing methods for automatic synthesis of Petri nets was presented in the scientific work of J. Peterson 1981 [4]. After J. Peterson's work it has appeared a number of scientific works linked to the automatic generation of Petri nets [5-7]. The certain synthesis methods based on the composition of individual Petri nets are presented in these works. The are not many scientific publications in this field, however, we can see the certain trend in the development of the corresponding scientific direction.

Taking into account the peculiarities of the synthesis of Petri nets, we have determined to form them on the basis of the functioning of an artificial neural network [8]. Thus, the artificial neural network is an intelligent system for the automatic synthesis of Petri nets and certain algorithms.

Currently there are lots of scientific publications linked to the integration of mathematical apparatus of Petri nets and artificial neural networks [9-11]. However, this integration is not linked to the automatic synthesis of Petri nets. Thereby, the organization of the joint functioning of the artificial neural network and Petri nets for the automatic synthesis of algorithms is presented in this article [8]. The first attempt in the development of methods for training of the artificial neural network linked to the synthesis of Petri nets is also presented in the scientific work [8].

The mathematical description of the process for training of the artificial neural network for the synthesis of Petri nets is considered in this paper. This synthesized Petri net represents the step-by-step algorithm for tuning the special class of coordinating automatic control systems shown in papers $[12,13]$.

\section{MATERIALS AND METHODS}

The features of automatic synthesis of Petri nets based on the functioning of the artificial neural network can be determined from Figure 1. The simplified block diagram of the coordinating control system with automatic tuning of its parameters is shown in Figure 1. This tuning of parameters in the regulators is occured on the basis of the joint functioning of the artificial neural network with the set of Petri nets. Petri nets marking determines the increment of the values for the corresponding parameters in the regulators to achieve the minimum value of the integral criteria of the control system. As shown in Figure 1 the artificial neural network interacts on the principles of feedback with synchronously functioning Petri nets. We can form the composition from these acting simultaneously nets. This composition will represent the certain algorithm of actions implemented by the artificial neural network. Figure 2a shows Petri net composition. This composition presents the algorithm for tuning the coordi- 
nating automatic control system. The functioning of such Petri net we can describe by the following equation:

$$
M_{k}=M_{k-1}+|A| \cdot U_{k}
$$

Where $M_{k}=\left|\mu\left(p_{0}\right), \ldots \mu\left(p_{n}\right)\right|^{T} ; M_{k-1}$ is the marking of Petri net at $k$ - 1 step.

In this case, if $\mu\left(p_{i}\right)=1$ (where $i=1 \ldots \mathrm{n}$ ), then the value of the corresponding parameter changes during tuning up of the system.

If we consider that the simplified structural diagram shown in Figure 1 represents logical-dynamic model, then the discrete-event part of the model can be described by the following equation:

$$
X_{L}^{d}\left(t_{k}\right)=X_{L}^{d}\left(t_{k-1}\right)+|W| \cdot v_{L}^{d}\left(t_{k}\right)+u_{L}^{d}\left(t_{k}\right),
$$

where $\quad X_{L}^{d}\left(t_{k}\right)=\left[\mu\left(p_{1}^{2}\right), \mu\left(p_{2}^{2}\right), \ldots \mu\left(p_{8}^{2}\right)\right]^{T} ; \quad X_{L}^{d}\left(t_{k}\right)$, $X_{L}^{d}\left(t_{k-1}\right)$ is discrete states in times $t_{k}, t_{k-1}$.

If the place $p_{l}$ is marked $-\mu\left(p_{1}\right)=1$ then $\kappa_{l}$ parameter should be increased i.e., $\mu\left(p_{1}\right)=1 \Rightarrow \uparrow k_{1}$ in this way $\mu\left(p_{2}\right)=1 \Rightarrow \downarrow k_{1}, \quad \mu\left(p_{3}\right)=1 \Rightarrow \uparrow k_{2}, \quad \mu\left(p_{4}\right)=1 \Rightarrow \downarrow k_{2}$,

$$
\begin{aligned}
& \mu\left(p_{5}\right)=1 \Rightarrow \uparrow k_{3}, \quad \mu\left(p_{6}\right)=1 \Rightarrow \downarrow k_{3}, \quad \mu\left(p_{7}\right)=1 \Rightarrow \uparrow k_{4}, \\
& \mu\left(p_{8}\right)=1 \Rightarrow \downarrow k_{4} .
\end{aligned}
$$

According to Figure $1, k_{1}$ is the tuning parameter of the Controller 1 in the coordinating control level, $k_{2}$ is the tuning parameter of the Controller $2, k_{3}$ is the tuning parameter of the Controller 3 in the stabilizing control level.

The equations (2) describe the joint functioning of Petri nets and the artificial neural network.

The incidence matrix of Petri net $|A|$ has the certain analogy with the matrix of the weights of the output layer in the neural network. So the artificial neural network generates the output signals $\bar{V}=|A| \cdot U_{k}$ corresponding to the values of the incidence matrix of the formed Petri net.

When tuning up of the system if the certain algorithm of actions is wrong then we must indicate the element of the Petri net which is erroneous. This is necessary for the reconfiguring of artificial neural network. For example, as shown in Figure 2, if the value of the integral indicators of the system increases, then it is necessary to eliminate the connection between the transition $t_{i}$ and the place $p_{i}$ respectively.

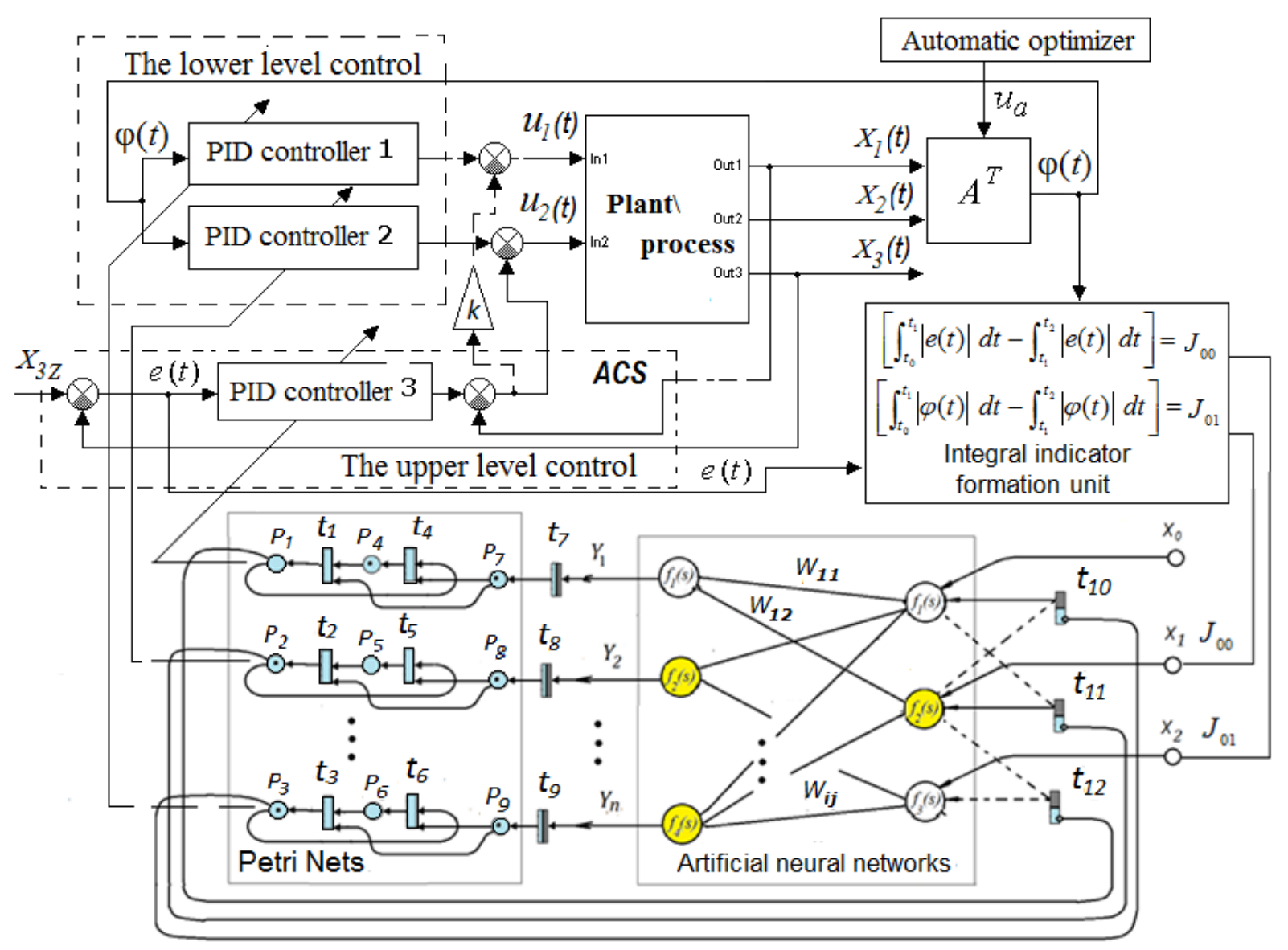

Figure 1 - The simplified block diagram of the coordinating automatic control system with automatic tuning of its parameters 
But in this case it is necessary to add the new connection between the transition $t_{i}$ and the neighboring place $p_{i+1}$. Thus, the Petri net shown in Figure 2a changes to the Petri net shown in Figure 2b. The coefficients of interneural connections in the artificial neural network must change accordingly.

It can be represented mathematically like this:

$$
\begin{gathered}
w_{i, j}\left(t_{k+1}\right)=w_{i, j}\left(t_{k}\right)-w_{i, j}\left(t_{k}\right) \cdot\left(\delta_{p, i}+\right. \\
\left.+\delta_{p, i+1}\right)+w_{i-1, j}\left(t_{k}\right) \cdot \delta_{p, i}+w_{i+1, j}\left(t_{k}\right) \cdot \delta_{p, i+1} \\
i=1,3,5 \ldots \\
\begin{array}{c}
w_{i, j}\left(t_{k+1}\right)=w_{i, j}\left(t_{k}\right)-w_{i, j}\left(t_{k}\right) \cdot\left(\delta_{p, i}+\right. \\
\left.+\delta_{p, i-1}\right)+w_{i+1, j}\left(t_{k}\right) \cdot \delta_{p, i}+w_{i-1, j}\left(t_{k}\right) \cdot \delta_{p, i-1} \\
i=2,4,6 \ldots \\
w_{i, j}\left(t_{k+1}\right)=w_{i, j}\left(t_{k}\right)-\delta_{t, j} \cdot w_{i, j}\left(t_{k}\right)+ \\
+\delta_{i, j} \cdot w_{i-1, j}\left(t_{k}\right) \\
\text { if } i=1,3,5 \ldots \\
w_{i, j}\left(t_{k+1}\right)=w_{i, j}\left(t_{k}\right)-\delta_{i} \cdot w_{i, j}\left(t_{k}\right)+ \\
+\delta_{i} \cdot w_{i+1, j}\left(t_{k}\right) \\
\text { if } i=2,4,6 \ldots
\end{array}
\end{gathered}
$$

Where $w_{i, j}\left(t_{k+1}\right)$ is the synaptic weight at step $t_{k+1}$.

In this instance the matrix of the coefficients for interneural connections of the output layer of the neural network we can show as:

$$
N=\left[\begin{array}{ccccccc}
w_{11} & w_{12} & w_{13} & \ldots & w_{1 j} & w_{1 j+1} & \ldots \\
w_{21} & w_{22} & & \ldots & w_{2, j} & w_{2, j+1} & \ldots \\
: & : & & & : & : & \\
w_{i, 1} & w_{i, 2} & & \ldots & w_{i, j} & w_{i, j+1} & \ldots \\
w_{i+1,1} & w_{i+1,2} & & \ldots & w_{i+1, j} & w_{i+1, j+1} & \ldots
\end{array}\right]
$$

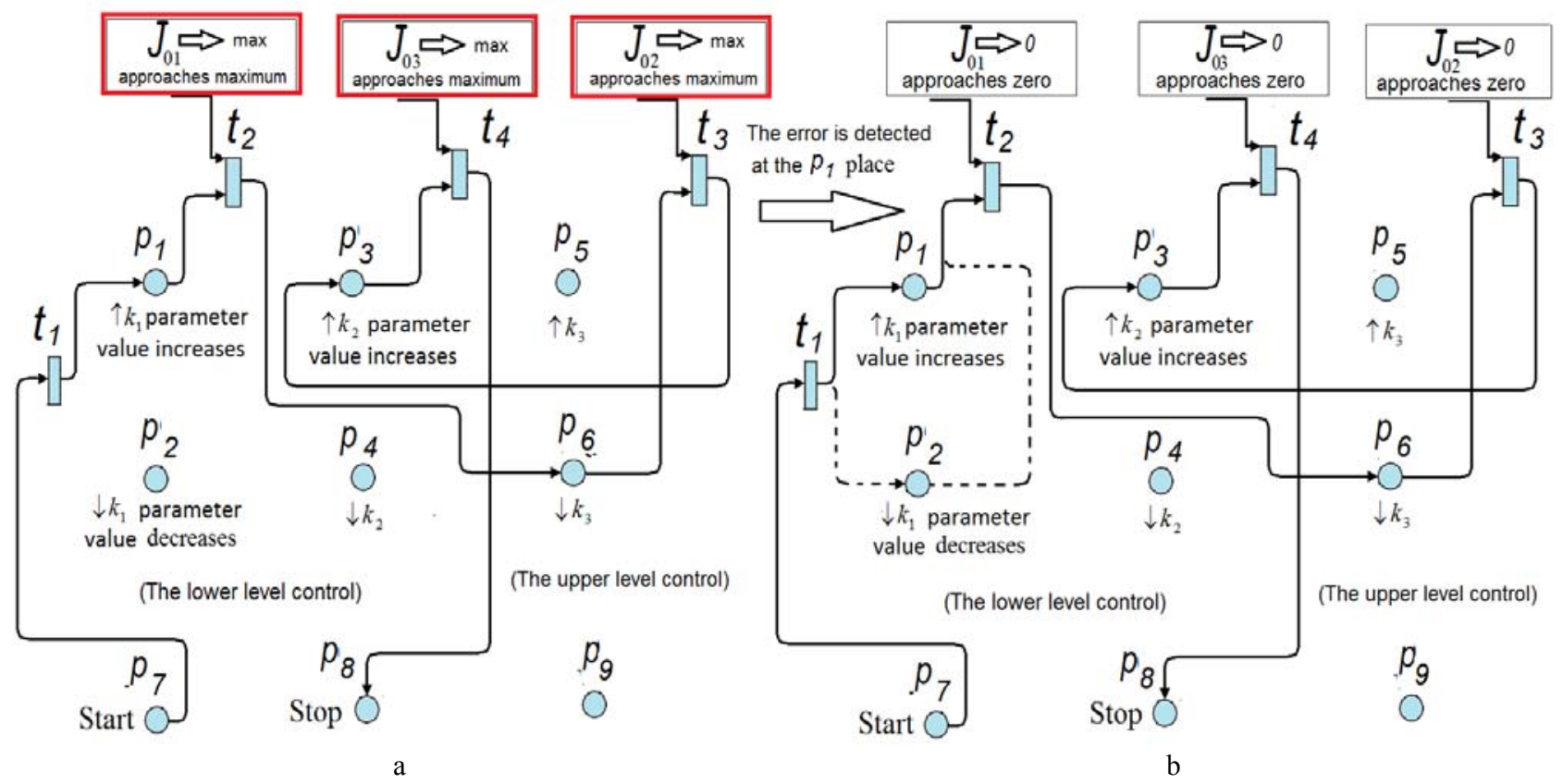

Figure 2 - The Petri nets representing the tuning algorithms of the coordinating automatic control system
The matrix $N$ of coefficients of interneuronal connections has a certain analogy with the incident matrix of Petri net. For example, the matrix $N$ is analogous to the incident matrix $W_{1}$ of Petri net shown in Figure 2a. If the place $p_{1}$ has the error then the incident matrix $W_{1}$ changes accordingly into the matrix $W_{2}$ as follows:

$$
\begin{aligned}
& \begin{array}{llll}
t_{1} & t_{2} & t_{3} & t_{4}
\end{array} \\
& \begin{array}{lllll}
p_{1} & +1 & -1 & 0 & 0
\end{array} \\
& p_{2} \quad 0 \quad 0 \quad 0 \quad 0 \\
& \begin{array}{lllll}
p_{3} & 0 & 0 & +1 & -1
\end{array} \\
& W_{1}=\begin{array}{ccccc}
p_{4} & 0 & 0 & 0 & 0 \\
p_{5} & 0 & 0 & 0 & 0
\end{array} \Rightarrow W_{2}{ }^{\prime} \\
& \begin{array}{lllll}
p_{6} & 0 & +1 & -1 & 0
\end{array} \\
& \begin{array}{lllll}
p_{7} & -1 & 0 & 0 & 0
\end{array} \\
& \begin{array}{lllll}
p_{8} & 0 & 0 & 0 & +1
\end{array} \\
& \begin{array}{lllll}
p_{9} & 0 & 0 & 0 & 0
\end{array} \\
& \begin{array}{llll}
t_{1} & t_{2} & t_{3} & t_{4}
\end{array} \\
& \begin{array}{lllll}
p_{1} & 0 & 0 & 0 & 0
\end{array} \\
& \begin{array}{lllll}
p_{2} & +1 & -1 & 0 & 0
\end{array} \\
& \begin{array}{lllll}
p_{3} & 0 & 0 & +1 & -1
\end{array} \\
& W_{2}=\begin{array}{lllll}
p_{4} & 0 & 0 & 0 & 0 \\
p_{5} & 0 & 0 & 0 & 0
\end{array} . \\
& \begin{array}{lllll}
p_{6} & 0 & +1 & -1 & 0
\end{array} \\
& \begin{array}{lllll}
p_{7} & -1 & 0 & 0 & 0
\end{array} \\
& \begin{array}{lllll}
p_{8} & 0 & 0 & 0 & +1
\end{array} \\
& \begin{array}{lllll}
p_{9} & 0 & 0 & 0 & 0
\end{array}
\end{aligned}
$$


The $p_{1}$ and $p_{2}$ rows of $W_{1}$ matrix were changed according to expressions (3).

if an error is detected at the $p_{i}$ or $p_{i+1}$ place then we have $\delta_{p, i}=1$ or $\delta_{p, i+1}=1$ accordingly. In this instance if there is a connection between the transition $t_{i}$ and the place $p_{i}$ then $w_{i, j}\left(t_{k}\right) \cdot\left(\delta_{p i}+\delta_{p i+1}\right)=|1|$. So according to the expression, the coefficients of interneuronal connections at a $t_{k+1}$ step will become equal to zero $w_{i, j}\left(t_{k+1}\right)=0$. Thus the corresponding connections with the place $p_{i}$ in the forming Petri net will disappear. In so doing the new connections must appear with the place $p_{i}$ if $w_{i-1, j}\left(t_{k}\right) \cdot \delta_{p, i}=1$ or if $w_{i+1, j}\left(t_{k}\right) \cdot \delta_{p, i+1}=1$.

Similarly, if an error is detected at the transition $t_{j}$ then we have $\delta_{t, j}=1$ accordingly. In this instance if there is a connection $\delta_{t, j} \cdot w_{i, j}\left(t_{k}\right)=1$ and $w_{i, j}\left(t_{k+1}\right)=0$. In the absence of connection $\delta_{i, j} \cdot w_{i+1, j}\left(t_{k}\right)=1 \quad$ and $w_{i, j}\left(t_{k+1}\right)=1$.

\section{EXPERIMENTS}

In the software environment MATLAB \Simulink 2012 the experiments were carried out linked to the joint functioning of the artificial neural network with the Petri nets. The functioning of Petri nets in the MATLAB Simulink software environment was implemented using a Stateflow diagram. The fragment of Stateflow diagram representing the functioning of Petri nets is shown in Figure 3. State 1, State 2, State 3 and State 4 are states of the same Petri net. The artificial neural network is linked with the functioning of three such Petri nets at once. This is shown in Figure 4. Figure 4 is also shown the two-layer artificial neural network implemented by means of the MATLAB \Simulink environment. This artificial neural network consists of six neurons and has three output signals $X p 1, X p 2, X p 3$ connected with Petri nets.

The structural diagram of the neural network and Petri nets is similar to the simplified diagram shown in Figure 1. In Figures 3 and 4 we can see all the necessary parameters of a system representing the joint functioning of the neural network and Petri nets. This system is intended for the automatic formation of Petri nets and certain algorithms.

\section{RESULTS}

The system shown by the block diagram in Figure 4 can represent the functioning of different Petri nets.

For example, Figures 4 and 5 we can see timing diagrams of the functioning of Petri net consisting of three positions and three transitions. The functioning of such Petri net is a system of joint function of the artificial neural network and Stateflow diagrams.

The output signals of the artificial neural network $X_{P I}$, $X_{P 2}, X_{P 3}$ correspond to the incidence matrix of the generated Petri net. The output signals $\mu\left(p_{1}\right), \mu\left(p_{2}\right), \mu\left(p_{3}\right)$ show the change in marking of Petri net for time. In this case the work of the formed Petri net is realized as shown in Figure 5.

According to timing diagrams, when we have the signal at $J_{1}$ input $\left(J_{01}>0\right)$ then transition $t_{2}$ is triggered. If we have the signal at $J_{2}$ input $\left(J_{01}>1\right)$ then transition $t_{3}$ is triggered. The simultaneous triggered of $t_{2}$ and $t_{3}$ transition corresponds to the conflict situation in the functioning of the Petri net.

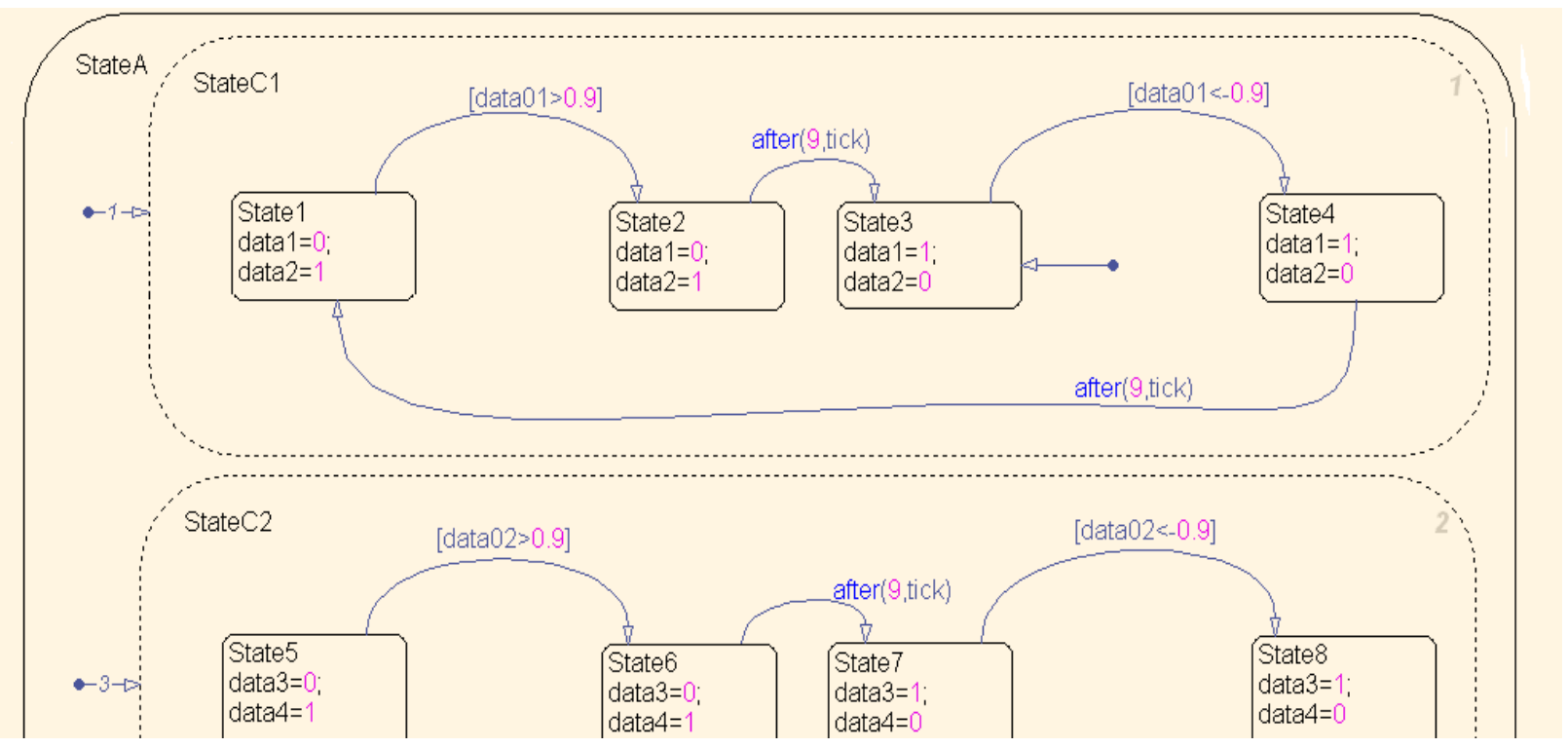

Figure 3 - Stateflow diagrams representing the functioning of Petri nets 


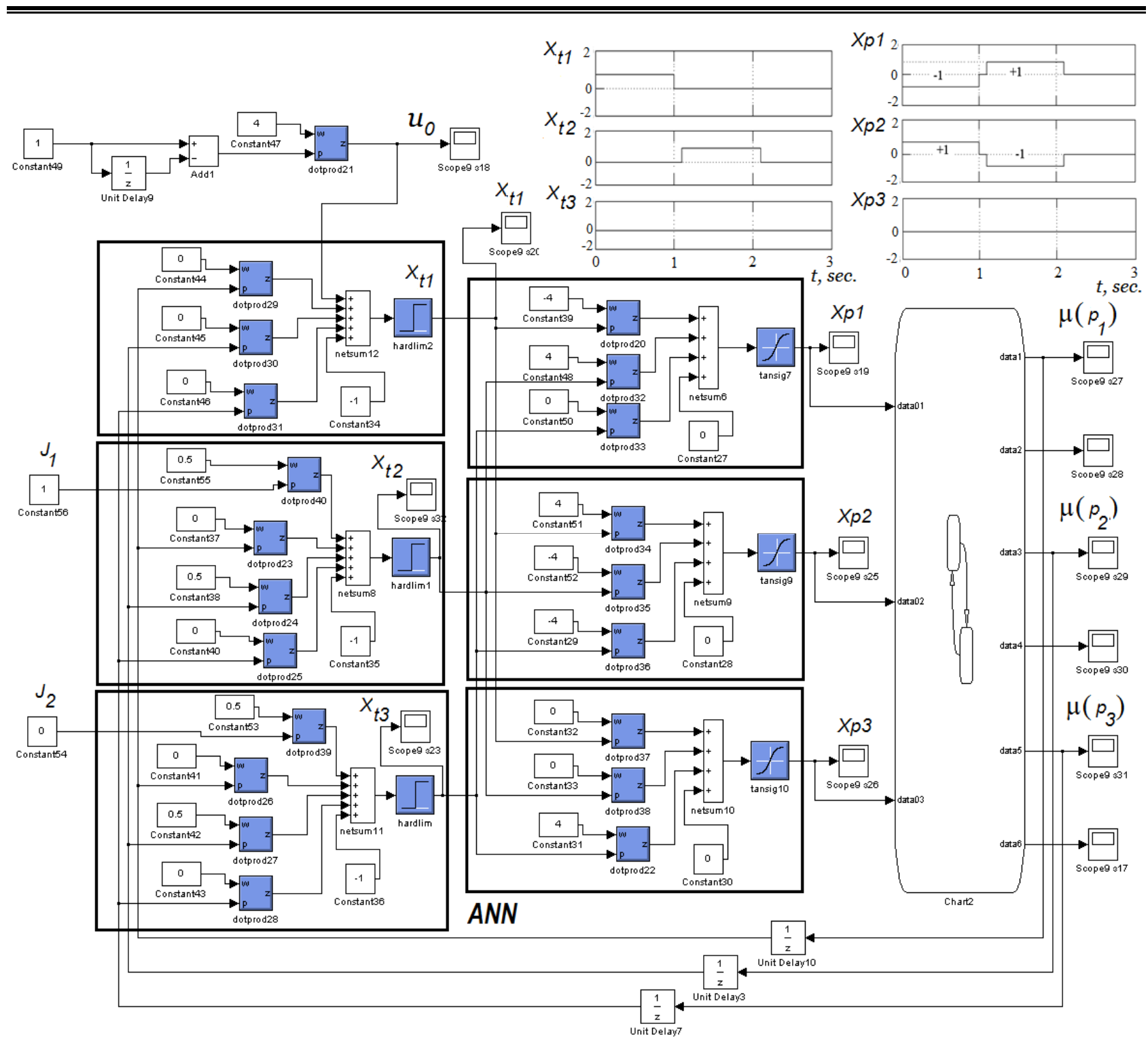

Figure 4 - Block diagram of the neural network implementing the synthesis of Petri net
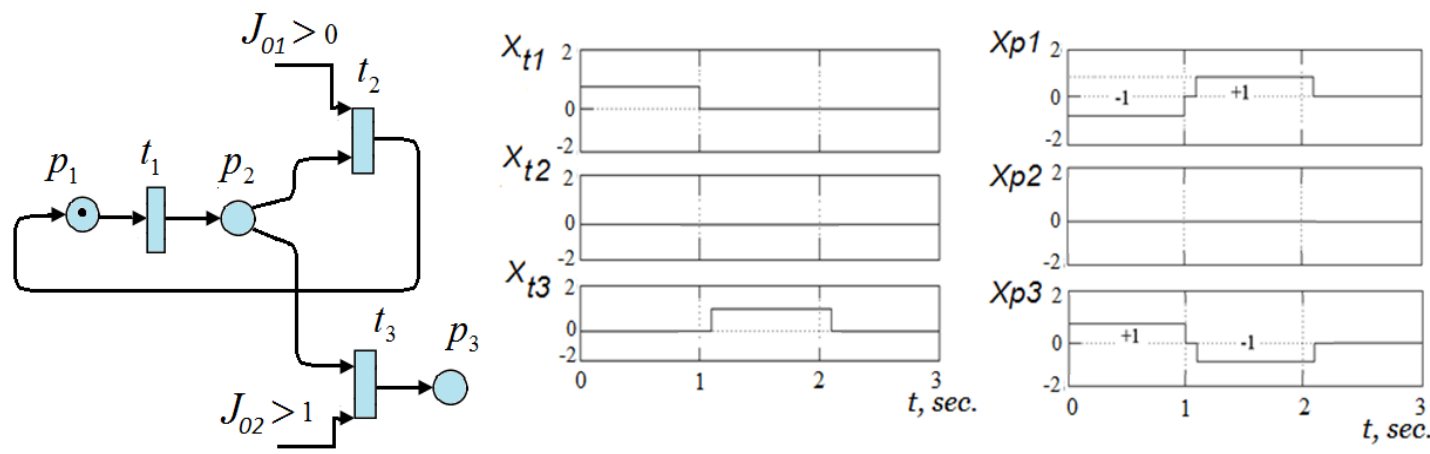

Figure 5 - The timing diagrams of the functioning of the synthesized Petri net

Analyzing the temporal characteristics we can conclude about the principal suitability of the considered system presented in Figures 4 and 5.This system is able to represent the functioning of various Petri nets. Tuning the parameters of an artificial neural network of such system (c) Gurskiy A. A., Denisenko A. V., Dubna S. M., 2021 DOI 10.15588/1607-3274-2021-2-9 is linked with the automatic synthesis of Petri net. Thus, the change in the coefficients of interneuronal connections when tuning the network is linked with the change in the synthesized Petri net. 


\section{DISCUSSION}

The automatic synthesis of Petri nets we can imagine in two stages. At the first stage the system realizes the selection of a certain algorithm and the corresponding Petri net among the possible variants. At the second stage the system realizes the correction of the selected algorithm and Petri net.

These two stages can be realized using an artificial neural network and its tuning up. For this case the system of joint functioning of the artificial neural network with Petri nets was designed (Figure 5). In order to compose the data of Petri nets into one common network we can use the output signals of the artificial neural network. These signals are required to form the corresponding incidence matrix.

If the generated Petri net is unsatisfactory then we must indicate which net element has the error. Then the system has to start the corresponding change in the coefficients of the interneural connections in the neural network.

The mathematical description of the change in the coefficients for interneuronal connections during training of the network was presented in the scientific work as one of the attempts to implement the enumeration of possible variants of connections in Petri net [14]. In this case the formed Petri net is a peculiar visual reflection of the coefficient set of interneural connections in the artificial neural network.

\section{CONCLUSIONS}

The scientific novelty of the results. The problem linked to with the development of the system for the joint functioning of the artificial neural network and Petri nets was solved in the present work. The developed system is necessary for providing of the automatic synthesis of some algorithms. Thus the corresponding method of automatic synthesis of Petri net has got the further development. In this paper we have presented the algorithm of change in the coefficients of interneural connections of the network during the synthesis of Petri net.

The practical significance of the results. The completed scientific research has confirmed the suitability of the developed system of the joint functioning of the artificial neural network and Petri nets for providing the automatic synthesis for some algorithms. Due to the method of automatic synthesis of Petri nets we can solve the problem of automatized tuning for models of the complicated control systems providing the coordination of various transients.

The prospects for further research. Further development of the scientific direction must be directly related to the formation of training methods of neural networks for the synthesis of Petri nets. It is also necessary to develop more complex models of systems showing the joint functioning of an artificial neural network and Petri nets.

\section{ACKNOWLEDGMENTS}

The scientific work was carried out at the department of technological processes automation and robotic systems.

The authors thank the management of the Odessa Refinery Plant too. The Odessa Refinery Plant has given the experimental data for designing models of the coordinating automatic control system.

\section{REFERENCES}

1. Yang Z., Blanke M. A unified approach to controllability analysis for hybrid control systems, Nonlinear Analysis: Hybrid Systems, 2007, Volume 1, Issue 2, pp. 212-222. DOI: 10.1016/j.nahs.2006.08.002

2. Drighiciu, M. A. Hybrid Petri nets: A framework for hybrid systems modeling, 2017 International Conference on Electromechanical and Power Systems (SIELMEN), IEEE, 2017, pp. 020-025. DOI: 10.1109 /SIELMEN. 2017. 8123285

3. Filimonov A. B., Filimonov N. B. O problematike sinteza koordiniruyuschih sistem avtomaticheskogo upravleniya, $I z-$ vestiya SfedU, Engineering sciences, 2012, Vol. 3, pp. 172 180. ISSN 1999-9429 2311-3103

4. Peterson, J. L. Petri net theory and the modeling of systems / Prentice Hall PTR, 1981, 290 p. ISBN 0-13-661983-5

5. He D. W., Strege B., Tolle H., Kusiak A. Decomposition in automatic generation of Petri nets for manufacturing system control and scheduling, International Journal of Production Research, 2000, Volume 38, Issue 6, pp. 1437-1457. DOI: 10.1080/002075400188942

6. Ndiaye M. A., Petin J. F., Camerini J., Georges J. P. Performance assessment of industrial control system during pre-sales uncertain context using automatic Colored Petri Nets model generation, 2016 International Conference on Control, Decision and Information Technologies (CoDIT), IEEE, 2016, pp. 671-676. DOI: 10.1109/CoDIT.2016.7593643

7. Durmuş M. S., Yıldırım U., Söylemez M. T. Automatic generation of Petri Net supervisors for railway interlocking design, 2012 2nd Australian Control Conference, IEEE, 2012, pp. 180-185. ISBN: 978-1-922107-63-3

8. Gurskiy A. A., Dubna S. M. Nastro1ka neironno1 set1 pr1 avtomaticheskom sinteze sete1 Petr1, Automation of technological and business processes, 2018, No. 1, pp. 22-32. DOI: https://doi.org/10.15673/ atbp.v10i1.877

9. Ahson, S. I. Petri net models of fuzzy neural networks, IEEE Transactions on systems, man, and cybernetics, 1995, Volume 38, Issue 6, pp. 926-932. ISSN: 2168-2909

10. Chow T. W., Li J. Y. Higher-order Petri net models based on artificial neural networks, Artificial Intelligence, 1997, Volume 92, Issues 1-2, pp. 289-300. DOI: https://doi.org/10.1016/S0004-3702(96)00048-3

11. Hanna M. M., Buck A., Smith R. Fuzzy Petri nets with neural networks to model products quality from a CNC-milling machining centre, IEEE Transactions on Systems, Man, and Cybernetics-Part A: Systems and Humans, 1996, Vol. 26, Issue 5, pp. 638-645. ISSN: 1558-2426. DOI: $10.1109 / 3468.531910$

12. Boichuk L. M. Sintez koordinirujushhih sistem avtomaticheskogo upravlenija. Moscow, Energoatomizdat, 1991, 160 p. ISBN 5-283-01521-1

13. Gurskiy A. A., Goncharenko A. E., Dubna S. M. Algorithms for tuning of the coordinating automatic control systems [Text], Radio electronics, computer science, control, 2020, 
No. 1, pp. 190-199. DOI: https://doi.org/10.15588/1607-

3274-2020-1-19
14. Sutton, R. S., Barto A. G. Reinforcement learning: An introduction, MIT press, 2018, 322 p. ISBN 0-262-19398-1

Received 26.01.2021 Accepted 18.04.2021

\section{УДК 681.513}

\section{АВТОМАТИЧНИЙ СИНТЕЗ МЕРЕЖ ПЕТРІ НА ОСНОВІ ФУНКЦІОНУВАННЯ ШТУЧНОЇ НЕЙРОННОЙ} МЕРЕЖI

Гурський О. О. - канд. техн. наук, доцент кафедри автоматизації технологічних процесів і робототехнічних систем інституту комп'ютерних систем і технологій «Індустрія 4.0» ім. П. Н. Платонова Одеської національної академії харчових технологій, Одеса, Україна.

Денисенко А. В. - старший викладач кафедри інформаційних систем Одеського національного політехнічного університету, Одеса, Україна.

Дубна С. М. - старший викладач кафедри автоматизації технологічних процесів і робототехнічних систем інституту комп’ютерних систем і технологій «Індустрія 4.0» ім. П. Н. Платонова Одеської національної академії харчових технологій, Одеса, Україна.

\section{АНОТАЦІЯ}

Актуальність. Вирішена актуальна задача, що пов'язана з розробкою методів автоматичного синтезу мереж Петрі для настроювання координувальних систем автоматичного управління. Важливість розробки даних методів обумовлена розвитком інтелектуальних систем, що забезпечують автоматизацію трудомістких процесів, в окремому випадку це настроювання певного класу складних систем управління.

Мета роботи - мінімізація часу та автоматизація процесу настроювання багаторівневих координувальних систем автоматичного управління.

Метод. Запропоновано принцип автоматичного синтезу мереж Петрі та певних алгоритмів настроювання складних систем управління на основі функціонування штучної нейронної мережі. Представлений математичний опис методу зміни коефіцієнтів міжнейронних зв'язків мережі при синтезі мереж Петрі.

Результати. У програмному середовищі Matlab $\backslash$ Simulink 2012a були проведені експерименти, пов'язані зі спільним функціонуванням штучної нейронної мережі і мереж Петрі. Функціонування мереж Петрі в середовищі Matlab $\backslash$ Simulink було представлено за допомогою Statflow діаграм.

У результаті експериментів були отримані часові характеристики функціонування штучної нейронної мережі, яка забезпечує композицію мереж Петрі. На основі часових характеристик була встановлена принципова придатність застосування штучної нейронної мережі для забезпечення автоматичної композиції мереж Петрі.

Висновки. У даній роботі було вирішено задачу, яка пов'язана з розробкою системи спільного функціонування нейронної мережі і мереж Петрі для формування алгоритмів і послідовних обчислень. Тим самим, одержали подальший розвиток методика автоматичного синтезу мереж Петрі та методика розробки певних алгоритмів на основі функціонування нейронної мережі.

КЛЮЧОВІ СЛОВА: штучна нейронна мережа, мережі Петри, автоматичний синтез, координувальна система, алгоритм настроювання.

УДК 681.513

\section{АВТОМАТИЧЕСКИЙ СИНТЕЗ СЕТЕЙ ПЕТРИ НА ОСНОВЕ ФУНКЦИОНИРОВАНИЯ ИСКУССТВЕННОЙ} НЕЙРОННОЙ СЕТИ

Гурский А. А. - канд. техн. наук, доцент кафедры автоматизации технологических процессов и робототехнических систем института компьютерных систем и технологий «Индустрия 4.0» им. П. Н. Платонова Одесской национальной академии пищевых технологий, Одесса, Украина.

Денисенко А. В. - старший преподаватель кафедры информационных систем Одесского национального политехнического университета, Одесса, Украина.

Дубна С. М. - старший преподаватель кафедры автоматизации технологических процессов и робототехнических систем института компьютерных систем и технологий «Индустрия 4.0» им. П. Н. Платонова Одесской национальной академии пищевых технологий, Одесса, Украина.

\section{АННОТАЦИЯ}

Актуальность. Решена актуальная задача, связанная с разработкой методов автоматического синтеза сетей Петри для настройки координирующих систем автоматического управления. Важность разработки данных методов обусловлена развитием интеллектуальных систем, обеспечивающих автоматизацию трудоемких процессов, в частном случае это настройка определенного класса сложных систем управления.

Цель работы - минимизация времени и автоматизация процесса настройки многоуровневых координирующих систем автоматического управления. 
Метод. Предложен принцип автоматического синтеза сетей Петри и определенных алгоритмов настройки сложных систем управления на основе функционирования искусственной нейронной сети. Представлено математическое описание метода изменения коэффициентов межнейронных связей сети при синтезе сетей Петри.

Результаты. В программной среде Matlab $\backslash$ Simulink 2012а были проведены эксперименты, связанные с совместным функционированием искусственной нейронной сети и сетей Петри. Функционирование сетей Петри в cpeде Matlab $\backslash$ Simulink было представлено с помощью Statflow диаграмм.

В результате экспериментов были получены временные характеристики функционирования искусственной нейронной сети, обеспечивающей композицию сетей Петри. На основе временных характеристик была установлена принципиальная пригодность применения искусственной нейронной сети для обеспечения автоматической композиции сетей Петри.

Выводы. В настоящей работе была решена задача, связанная с разработкой системы совместного функционирования нейронной сети и сетей Петри для формирования алгоритмов и последовательных вычислений. Тем самым, получили дальнейшее развитие методика автоматического синтеза сетей Петри и методика разработки определенных алгоритмов на основе функционирования нейронной сети.

КЛЮЧЕВЫЕ СЛОВА: искусственная нейронная сеть, сети Петри, автоматический синтез, координирующая система, алгоритм настройки.

\section{ЛІТЕРАТУРА / ЛИТЕРАТУРА}

1. Yang Z. A unified approach to controllability analysis for hybrid control systems / Z. Yang, M. Blanke // Nonlinear Analysis: Hybrid Systems. - 2007. - Volume 1, Issue 2. P. 212-222. DOI: 10.1016/j.nahs.2006.08.002

2. Drighiciu M. A. Hybrid Petri nets: A framework for hybrid systems modeling / M. A. Drighiciu // 2017 International Conference on Electromechanical and Power Systems (SIELMEN) - IEEE, 2017. - P. 020-025. DOI: 10.1109 /SIELMEN. 2017. 8123285

3. Филимонов А. Б. О проблематике синтеза координирующих систем автоматического управления / А. Б. Филимонов, Н. Б. Филимонов // Известия Южного федерального университета. Технические науки. - 2012. T. 128, № 3. - C. 172-180.

4. Peterson J. L. Petri net theory and the modeling of systems / J. L. Peterson. - Prentice Hall PTR, 1981. - 290 p. ISBN 013-661983-5

5. Decomposition in automatic generation of Petri nets for manufacturing system control and scheduling / [D. W. He, B. Strege, H. Tolle, A. Kusiak] // International Journal of Production Research - 2000. - Volume 38, Issue 6. P. 1437-1457. DOI: 10.1080/002075400188942

6. Performance assessment of industrial control system during pre-sales uncertain context using automatic Colored Petri Nets model generation / M. A. Ndiaye, J. F. Petin, J. Camerini, J. P. Georges // 2016 International Conference on Control, Decision and Information Technologies (CoDIT) - IEEE, 2016. - P. 671-676. DOI: 10.1109/CoDIT.2016.7593643

7. Durmuş M. S. Automatic generation of Petri Net supervisors for railway interlocking design / M. S. Durmuş, U. Yıldırım,
M. T. Söylemez // 2012 2nd Australian Control Conference. - IEEE, 2012. - P. 180-185. ISBN: 978-1-922107-63-3

8. Гурский А. А. Настройка нейронной сети при автоматическом синтезе сетей Петри / А. А. Гурский, С. М. Дубна // Автоматизация технологических и бизнеспроцессов. - Одесса: 2018. -Т. 10, № 1. - С. 22 -32.

9. Ahson, S. I. Petri net models of fuzzy neural networks / S. I. Ahson // IEEE Transactions on systems, man, and cybernetics - 1995. - Volume 38, Issue 6. - P. 926-932. ISSN: 2168-2909

10. Chow T. W. Higher-order Petri net models based on artificial neural networks / T. W. Chow, J. Y. Li //Artificial Intelligence - 1997. - Volume 92, Issues 1-2. - P. 289-300. DOI: https://doi.org/10.1016/S0004-3702(96)00048-3

11. Hanna, M. M. Fuzzy Petri nets with neural networks to model products quality from a CNC-milling machining centre / M. M. Hanna, A. Buck, R. Smith // IEEE Transactions on Systems, Man, and Cybernetics-Part A: Systems and Humans - 1996. - Volume 26, Issue 5. - P. 638-645. ISSN: 1558-2426. DOI: 10.1109/3468.531910

12. Бойчук Л. М. Синтез координирующих систем автоматического управления / Л. М. Бойчук. - М. : «Энергоатомиздат», 1991. - $160 \mathrm{c}$.

13. Gurskiy, A. A. Algorithms for tuning of the coordinating automatic control systems / A. A. Gurskiy, A. E. Goncharenko, S. M. Dubna // Radio electronics, computer science, control. - 2020. - No. 1. - P. 190-199. DOI: https://doi.org/10.15588/1607-3274-2020-1-19

14. Sutton R. S. Reinforcement learning: An introduction / R. S. Sutton, A. G. Barto. - MIT press, 2018. - 322 p. ISBN 0-262-19398-1 